\title{
All Art is with the Crowd or the Police
}

\author{
Heath Schultz ${ }^{1}$
}

Partisan in tone, "All art is with the crowd or the police" draws clear battle lines. This piece of experimental writing collages texts from anti-capitalist activists, corporate news, critical theorists, poets, and press releases to form a quasi-unified voice "from the crowd" that works toward a position against representation. This hybridized voice is juxtaposed with excerpts from a police manual on riot control. The crowd contradicts itself as it grapples with what is possible to produce in struggle; the authoritarian voice of the police outlines methods for containment. Meandering through various events - the blockade, the protest march, the occupation - the conflicted voice weaves together conversations about art, gentrification, violence, whiteness, representation, community, and capitalism. [Article copies available for a fee from The Transformative Studies Institute. E-mail address: journal@transformativestudies.org Website: http://www.transformativestudies.org (C2021 by The Transformative Studies Institute. All rights reserved.]

KEYWORDS: Gentrification, Riot, Whiteness, Police, Anarchism.

With others, you move together, approaching something choreographed yet still improvised. There are signs blocking your view but they are inconsequential. You can see as part of the crowd, or better, you can feel as part of the crowd. Collective energy sees for everyone. You feel titillated by this collective vision and movement, but you look around and not everyone is on the same page. To your left the sign blocking your view says "Love conquers Hate." You think this phrase is ahistorical and you don't know what it means unless it means we are not

\footnotetext{
${ }^{1}$ Heath Schultz is a research-based artist and writer. His work engages a critique of white supremacy, liberalism, and capitalist ideologies. His writing has been published in Lateral, Radical Teacher, Parallax, and the Journal of Aesthetics and Protest, in addition to various DIY publications. His work has been shown at the New Zealand Film Archive, Auckland, New Zealand; Visual Arts Center, Austin; Experimental Response Cinema, Austin; and Plains Art Museum, Fargo, ND, to name a few. He is an assistant professor of art at the University of Tennessee at Chattanooga. You can view his work at heathschultz.com. Address correspondence to: Heath Schultz, e-mail:

Schultz.heath@gmail.com.
} 